\title{
Dampak Residu Pestisida Regent Terhadap Survival Rate Ikan Mas (Cyprinus carpion Linn)
}

\author{
Mimatun Nasihah ${ }^{1 *}$, Adisti Risma Putri ${ }^{2}$, Nurul Dwi Khasanah ${ }^{2}$ \\ ${ }^{1}$ Dosen Prodi Kesehatan Lingkungan Fakultas Ilmu Kesehatan Unisla \\ 2,3Mahasiswa Prodi Kesehatan Lingkungan Fakultas Ilmu Kesehatan Unisla \\ * Correspondence author: mima@unisla.ac.id; Tel.: 082331602188
}

Received: 18 Februari 2021; Accepted: 9 Maret 2021; Published: 10 Maret 2021

\begin{abstract}
Abstrak
Limbah yang masuk ke perairan, salah satunya adalah limbah yang berasal dari pertanian yakni pestisida. Berbagai pestisida digunakan sebagai pengendali hama untuk meningkatkan produksi pertanian. Pestisida yang masuk dalam jumlah yang besar dapat bersifat racun bagi biota-biota yang hidup di perairan, antara lain adalah ikan-ikan. Penggunaan pestisida untuk membasmi hama baik secara langsung ataupun tidak langsung akan mengganggu kualitas air, sehingga kelangsungan hidup dan pertumbuhan ikan juga akan terganggu. Kelangsungan hidup ikan sangat tergantung dari kondisi perairan tempat hidupnya. Mengingat besarnya potensi pencemaran dari limbah pestisida dalam perairan, dan adanya perbedaan kepentingan tersebut, maka pemakaian pestisida kiranya perlu dilakukan secara cermat. Penelitian ini bertujuan untuk mengetahui kemampuan hidup rata-rata ikan mas yang terdampak oleh residu pestisda. Metode penelitian menggunakan metode eksperimen dengan variasi konsentrasi pestisida sebagai variable bebas dan survival rate ikan mas sebagaia variable terikatnya. Hasil penelitian menunjukan bahwa rata-rata ikan Mas mati dalam waktu ke 10 dengan konsentrasi tertinggi $20 \mathrm{ml} / \mathrm{l}$ air. Hasil uji ANOVA menunjukan bahwa nilai $\mathrm{F}$ hitung sebesar $39.0>\mathrm{F}$ tabel 8.7 hal ini menunjukan terdapat pengaruh perbedaan konsentrasi pestisida terhadap mortalitas ikan mas.
\end{abstract}

Kata kunci: Pestisida, Ikan Mas, Survival Rate 


\section{Pendahuluan}

Limbah yang masuk ke perairan, salah satunya adalah limbah yang berasal dari pertanian yakni pestisida. Berbagai pestisida digunakan sebagai pengendali hama untuk meningkatkan produksi pertanian. Pestisida yang masuk dalam jumlah yang besar dapat bersifat racun bagi biota-biota yang hidup di perairan, antara lain adalah ikan-ikan. Pestisida sering digunakan sebagai pilihan utama untuk memberantas organisme pengganggu tanaman sebab mempunyai daya bunuh yang tinggi, penggunaannya mudah dan hasilnya cepat diketahui. Namun bila aplikasinya kurang bijaksana dapat membawa dampak pada pengguna, hama non sasaran, maupun lingkungan yang sangat berbahaya (1).

Penggunaan pestisida untuk membasmi hama baik secara langsung ataupun tidak langsung akan mengganggu kualitas air, sehingga kelangsungan hidup dan pertumbuhan ikan juga akan terganggu. Menurut Thompson, 1971 (2) pengaruh secara langsung disebabkan oleh akumulasi pestisida dalam organ-organ tubuh akibat tertelan bersama-sama makanan yang terkontaminasi, atau akibat rusaknya organ-organ pernafasan sehingga dapat mematikan ikan budidaya dalam jangka waktu tertentu, sedangkan secara tidak langsung adalah menurunnya kekebalan tubuh terhadap penyakit dan terhambatnya pertumbuhan.

Ikan mas merupakan salah satu ikan air tawar yang mempunyai nilai ekonomis penting, sehingga ikan ini banyak dibudidayakan. Selain dipelihara dalam kolam-kolam tertentu, ikan mas sering dipelihara di sawah bersama-sama dengan tanaman padi. Kelangsungan hidup ikan sangat tergantung dari kondisi perairan tempat hidupnya. Mengingat besarnya potensi pencemaran dari limbah pestisida dalam perairan, dan adanya perbedaan kepentingan tersebut, maka pemakaian pestisida kiranya perlu dilakukan secara cermat. Oleh karena itu dilakukan penelitian yang bertujuan untuk mengetahui pengaruh penggunaan pestisida yang mengandung bahan aktif fipronil dengan konsentrasi yang berbeda terhadap pertumbuhan dan kelangsungan hidup (survival rate) ikan mas.

\section{Metode}

Penelitian ini dilakukan pada tanggal 12 Januari 2021 di Laboratorium Kesehatan Lingkungan Fakultas Ilmu Kesehatan Universitas Islam Lamongan.

Metode yang digunakan dalam penelitian ini adalah eksperimen. Dimana metode eksperimen adalah metode yang digunakan untuk mengetahui sebab akibat. Atau hubungan antara variable bebas yang mempengaruhi variable terikat. Variable bebas dalam hal ini adalah 
perbedaan kosentrasi pestisda dan variable terikatnya adalah pertumbuhan dan kelangsungan hidup (survival rate) ikan mas.

Langkah penelitian, yang pertama menyiapkan toples plastik transparan berukuran $2 \mathrm{~L}$ sebanyak 9 buah. Masing-masing toples diisi air sebanyak 1 liter. Kemudian di ukur ph air terlebih dahulu. Kemudian menyiapkan pestisida jenis regent dengan 3 macam perlakuan yakni $10 \mathrm{ml} /$ liter air, $25 \mathrm{ml} / \mathrm{liter}$ air dan air 1 liter sebagai kontrol. Penelitian ini diulang sebanyak 3 kali. Memasukan ikan pada masing-masing toples sebanyak 5 ekor ikan. Jadi jumlah total ikan yang digunakan sebanyak 45 ekor. Selanjutnya mengamati perilaku ikan pada menit ke 10. Perilaku yang diamati meliputi gerakan ikan, keluar lendir dari kulit ikan, keluar lender dan darah dari insang ikan, dan kematian ikan. Tahap terakhir mecatat data hasil pengamatan.

Alat dan bahan yang digunakan antara lain: toples plastik transparan ukuran $2 \mathrm{~L}, \mathrm{pH}$ meter, pengaduk, gelas ukur, reagent, ikan mas, kertas label.

Teknik pengumpulan dan analisis data. Pengamatan pertumbuhan dan kelangsungan hidup ikan mas setelah terpapar residu pestisida jenis reagent. Survival rate meliputi pergerakan ikan, ada tidaknya lendir dikulit ikan, ada tidaknya lendir dan darah dari insang ikan, dan kematian ikan. Analisis data menggunakan uji anova one way, untuk mengetahui perbedaan konsentrasi pestisida terhadap survival rate ikan mas.

\section{Hasil penelitian}

pH Air yang digunakan dalam menguji pengaruh pestisida jenis reagent terhadap survival rate ikan mas.

Tabel 1. Hasil pengukuran pH Air

\begin{tabular}{|l|l|l|l|l|}
\hline \multirow{2}{*}{ No } & \multirow{2}{*}{ Perlakuan } & \multicolumn{2}{|c|}{ pH } & \multirow{2}{*}{ Keterangan } \\
\cline { 3 - 4 } & Kontrol & $\begin{array}{c}\text { Air sebelum } \\
\text { perlakuan }\end{array}$ & $\begin{array}{c}\text { Air setelah } \\
\text { perlakuan }\end{array}$ & \\
\hline 1 & 7,34 & 6,93 & $\begin{array}{l}\text { Penuruan } \\
\text { sebesar 0,41 }\end{array}$ \\
\hline 2 & $10 \mathrm{ml} / 1$ L air & 7,38 & 7,05 & $\begin{array}{l}\text { Penurunan } \\
\text { sebesar 0,33 }\end{array}$ \\
\hline 3 & $25 \mathrm{ml} / 1 \mathrm{~L}$ air & 7,06 & 6,88 & $\begin{array}{l}\text { Penurunan } \\
\text { sebesar 0,18 }\end{array}$ \\
\hline & Rata-Rata & 7.2 & 6.9 & 0.30 \\
\hline
\end{tabular}

Dari tabel 1 diatas menunjukan bahwa $\mathrm{pH}$ air yang digunakan untuk mengamati pengaruh pestisida jenis reagent terhadap survival rate ikan mas. Rata-rata $\mathrm{pH}$ air sebelum digunakan sebesar 7.2, merupakan $\mathrm{pH}$ normal dari air. Setelah diberi pestisida jenis reagent, 
$\overline{\mathrm{pH}}$ air mengalami penurunan yakni sebesar 6.9, lebih asam dari sebelumnya. Dengan rata-rata penurunan $\mathrm{pH}$ sebesar 0.30 .

\section{Pengamatan terhadap Survival Rate Ikan Mas pada menit ke 10}

Tabel 2. Pengamatan Perilaku Ikan

\begin{tabular}{|c|c|c|c|c|c|}
\hline \multirow[t]{2}{*}{ No } & \multirow[t]{2}{*}{ Perlakuan } & \multicolumn{4}{|c|}{ Perilaku Ikan } \\
\hline & & Gerakan & $\begin{array}{c}\text { Ada/tidak } \\
\text { lender di } \\
\text { kulit }\end{array}$ & Lemas & Mati \\
\hline 1 & Kontrol & $\begin{array}{l}\text { Gerakan ikan } \\
\text { normal }\end{array}$ & Tidak ada & Tidak & Tidak \\
\hline 2 & $10 \mathrm{ml} / \mathrm{l}$ air & $\begin{array}{l}\text { Gerakan ikan } \\
\text { yang awalnya } \\
\text { tenang bergerak } \\
\text { menjadi resah } \\
\text { lalu perlahan } \\
\text { bergerak lambat }\end{array}$ & Ada & $\begin{array}{ll}\text { Ikan lemas } \\
\text { pada menit } \\
\text { ke } 5\end{array}$ & $\begin{array}{lr}\text { Ikan mati } \\
\text { semua pada } \\
\text { maneit ke } \\
10\end{array}$ \\
\hline 3 & $25 \mathrm{ml} / \mathrm{l}$ air & $\begin{array}{l}\text { Ikan bergerak } \\
\text { cepat hingga } \\
\text { meloncat dan } \\
\text { berputar-putar } \\
\text { dengan cepat }\end{array}$ & Ada & $\begin{array}{ll}\text { Ikan lemas } \\
\text { pada menit } \\
\text { ke } 4\end{array}$ & $\begin{array}{lr}\text { Pada } & \text { menit } \\
\text { ke } 8 & \text { ikan } \\
\text { sudah mati } & \text { semua }\end{array}$ \\
\hline
\end{tabular}

Pada tabel 2 menjelaskan tentang pengamatan pada perilaku ikan selama 10 menit. Pada 3 perlakuan diatas, gerakan ikan pada perlakuan control, ikan bergerak secara normal, pada perlakuan dengan pemberian pestisida sebesar $10 \mathrm{ml} /$ liter air ikan bergerak menjadi resah, pada perlakuan $25 \mathrm{ml} / \mathrm{l}$ air, ikan sangat gelisah dan bergerak sangat cepat.

Pada kontrol tidak keluar lendir pada permukaan kulitnya, sementara pada perlakuan $10 \mathrm{ml} / \mathrm{l}$ air dan perlakuan $25 \mathrm{ml} / \mathrm{l}$ air keluar lendir dari permukaan kulitnya.

Pengamatan terhadap kematian ikan. Pada kontrol tidak ada ikan yang mati. Pada perlakuan 10 $\mathrm{ml} / \mathrm{l}$ air ikan mati semua pada menit ke 10 dan pada perlakuan $25 \mathrm{ml} / \mathrm{l}$ air ikan mati semua pada menit ke 8 .

Uji ANOVA One Way perbedaan konsentrasi pestisida jenis reagent terhadap kematian ikan 
Tabel 3. Uji Anova Pengaruh Residu Pestisida Jenis Reagent Mortalitas Ikan Mas

\begin{tabular}{|l|r|r|r|r|r|}
\hline \multicolumn{7}{|c|}{ ANOVA } \\
\hline Perakuan & $\begin{array}{l}\text { Sum of } \\
\text { Squares }\end{array}$ & \multicolumn{1}{|c|}{ Df } & $\begin{array}{c}\text { Mean } \\
\text { Square }\end{array}$ & F & Sig. \\
\hline $\begin{array}{l}\text { Between } \\
\text { Groups }\end{array}$ & 7.500 & 1 & 7.500 & 39.000 & .000 \\
\hline Within Groups & 2.500 & 13 & .192 & & \\
\hline Total & 10.000 & 14 & & & \\
\hline
\end{tabular}

Hasil F Hitung dari Uji Anova One Way terhadap perbedaan konsentrasi perlakuan Pemberian Pestisida jenis reagent terhadap mortatlitas ikan mas dengan taraf kesalahan $5 \%$ sebesar 39 > dari nilai F Tabel 8.7, hal ini menunjukan terdapat perbedaan signifikan pada tiap perlakuan konsentrasi pestisida jenis reagent terhadap mortalitas ikan mas.

\section{Pembahasan}

\section{Pengamatan Pengaruh Pestisida terhadap Pertumbuhan Ikan}

Pada hasil pengamatan pengaruh pestisida terhadap pertumbuhan ikan, kami membuat tiga perlakuan dengan control 1 tanpa penambahan pestisida, control 2 dengan penambahan pestisida sebanyak 10ml, control 3 dengan penambahan pestisida sebanyak $25 \mathrm{ml}$. Pada control 1, sebelum dimasukkan ikan ke dalam air, $\mathrm{pH}$ sebesar 7,34 lalu setelah perlakuan dimasukkan ikan $\mathrm{pH}$ berubah menjadi 6,93. Hal ini terjadi karena banyaknya asam karbon dari sisa metabolism ikan (zat ammonia). Lalu pada control 2, sebelum dimasukkan ikan ke dalam air pH sebesar 7,38, lalu setelah dimasukkan ikan ke dalam air pH berubah menjadi 7,05. Penurunan $\mathrm{pH}$ pada air tidak teralu menurun, karena ikan menjaga karbon yang dikeluarkan dari sisa metabolism tubuh untuk mempertahankan hidup. Pada control 3, sebelum dimasukkan ikan ke dalam air, $\mathrm{pH}$ sebesar 7,06 berubah menjadi 6,88 setelah dimasukkan ikan. Hal ini juga sama seperti pada control 2 tetapi penurunan $\mathrm{pH}$ yang terjadi pada control 3 hanya sedikit, karena ikan mengurangi pengeluaran karbon pada saat metabolism.

Menurut Chervinsky (3) kisaran konsentrasi ammonia yang baik untuk kehidupan ikan adalah kurang dari 2,4 mg/L. Alabaster dan Llyod (4) mengatakan bahwa ammonia yang berada dalam jumlah yang relatif kecil bersifat toksik terhadap ikan. Semakin tinggi konsentrasi pestisida fipronil yang diujikan akan menyebabkan ammonia dalam perairan akan semakin tinggi. 


\section{Pengamatan Perilaku Ikan}

Pada hasil pengamatan ikan selama 10 menit, pada control 1 tanpa penambahan pestisida dalam air ikan bergerak normal hingga menit ke 10. Pada control 2 penambahan pestisida sebanyak 10ml pada air, ikan mulai bergerak resah pada menit ke-3, lalu mulai bergereak lambat pada menit ke-5, lalu pada menit ke-6 ada eberapa ikan yang mati hingga akhirnya mati pada menit ke 9. Pada control 3 dengan penambahan pestisida sebanyak $25 \mathrm{ml}$ ke dalam toples air, pada menit ke-2 ikan sudah mulai resah dan bergerak cepat. Hingga pada menit ke-5 ikan mulai lemas dan hampir tidak bergerak, pada meenit ke-7 ikan sudah mati semua.

Pengamatan secara visual selama penelitian terlihat bahwa ikan uji mengalami perubahan tingkah laku yang disebabkan karena adanya pengaruh dari bahan aktif fipronil yang terdapat dalam insektisida Regent 0,3G. Sudarmo (5) menyatakan ikan yang terkena racun bahan pencemar dapat diketahui dengan gerakan hiperaktif, menggelepar, lumpuh dan kemudian mati. Secara klinis hewan yang terkontaminasi racun memperlihatkan gejala stress bila dibandingkan dengan kontrol, ditandai dengan menurunnya nafsu makan, gerakan kurang stabil, dan cenderung berada di dasar. Hal ini diduga sebagai suatu cara untuk memperkecil proses biokimia dalam tubuh yang teracuni, sehingga efek lethal yang terjadi lebih lambat (6).

Pada saluran pernafasan pestisida dapat menyebabkan kerusakan pada bagian insang dan organ-organ yang berhubungan dengan insang. Masuknya pestisida dalam insang melalui kontak langsung, karena letaknya di luar. Alasbaster dan Lloyd (4) menyatakan kerusakan insang dapat berupa penebalan lamella, degradasi sel atau bahkan kerusakan dan kematian jaringan insang. Hal ini menyebabkan fungsi insang menjadi tidak wajar dan mengganggu proses respirasi, akibatnya mengganggu pernafasan dan akhirnya menyebabkan kematian.

Hasil uji Anova menunjukkan bahwa terdapat perbedaan yang signifikan antara perlakuan satu dengan yang lain dengan pemberian pestisida jenis reagent terhadap survival rate ikan mas. Artinya residu pestisida mempengaruhi survival rate ikan mas mulai dari perilakunya yang menjadi gelisah dengan bergerak sangat gesit, keluarnya lendir dari kulit ikan, keluarnya lendir dan darah dari insang ikan bahkan pada kematian ikan mas. Hal ini sesuai dengan penelitian yang dilakukan oleh (6) yang menyatakan hasil uji toksisitas sublethal menunjukkan bahwa pemberian pestisida bahan aktif fipronil dengan konsentrasi yang berbeda $(0,000 \mathrm{mg} / \mathrm{L} ; 0,084 \mathrm{mg} / \mathrm{L} ; 0,168 \mathrm{mg} / \mathrm{L} ; 0,252 \mathrm{mg} / \mathrm{L} ; 0,336 \mathrm{mg} / \mathrm{L})$ berpengaruh nyata terhadap pertumbuhan dan kelangsungan hidup benih ikan mas. 


\section{Kesimpulan}

Pada pembahasan diatas, dapat kami tarik kesimpulan bahwa Penambahan pestisida jenis regent dalam kadar yang banyak dapat mempengaruhi pertumbuhan dan prilaku ikan mas. Pestisida yang mengandung fipopronil sangat berbahaya digunakan dalam perairan yang terdapat ikan. Pengaruh tersebut yakni pada perilaku ikan menjadi gelisah dan gesit, keluar lendir di kulitnya, keluar lendir dan darah dari insang dan sampai pada kematian ikan.

\section{Daftar Pustaka}

1. Wudianto, R. 1994. Petunjuk Penggunaan Pestisida. Penebar Swadaya, Jakarta.

2. Thomson, R.C.M. 1971. Pesticides and Freshwater Fauna. Academic Press, London and New York.

3. Chervinsky, J. 1982. Environmental Physiology of Tilapia. In R.S.V. Pullin and R.H. Lowe. Mc Connel (Editors) The Biology and Culture of Tilapias. ICLARM. Conference Proceeding, ICLARM Manila

4. Alabaster, J. and Lloyd. 1980. Water Quality Criteria for Fish. FAO of United Nations European Inland Fisheries Advisor Commision, Butterworth London. Boston, 297 pp.

5. Sudarmo, S. 1991. Pestisida. Yogyakarta: Penerbit Kanisius.

6. Rudiyanti, S., \& Dana, A. (2009). Pertumbuhan dan survival rate ikan mas (Cyprinus carpio Linn) pada berbagai konsentrasi pestisida regent 0, 3 g. Saintek Perikanan, 5(1), 49-54 